\title{
Lithogeochemical characterization of the Beaverbank unit of the Halifax Formation, Meguma Group, and acid drainage implications
}

\author{
M. Feetham ${ }^{1}$, R.J. Ryan², G. Pe-Piper ${ }^{3}$ and A.M. O'Beime-Ryan ${ }^{3+4}$ \\ ${ }^{1}$ Kaoclay Resources, P.O. Box 262, Shubenacadie, Nova Scotia BON 2H0, Canada \\ ${ }^{2}$ Nova Scotia Department of Natural Resources, P.O. Box 698, Halifax, Nova Scotia B3J 2T9, Canada \\ ${ }^{3}$ Department of Geology, St. Mary's University, Halifax, Nova Scotia B3H 3C3, Canada \\ ${ }^{4}$ Department of Earth Science, Dalhousie University, Halifax, Nova Scotia B3H 3J5, Canada
}

Date Received September 10, 1996
Date Accepted June 24, 1997

\begin{abstract}
Lithogeochemical analyses of samples from the Beaverbank unit at North Beaverbank were used to characterize the stratigraphic interval representing the gradation from metasandstone of the Goldenville Formation to slate of the overlying Halifax Formation in central mainland Nova Scotia (central Meguma area). The unit can be divided into three subunits on the basis of lithology, chemistry, and mineralogy. Upper subunit A (the coticule horizon) consists principally of grey sulphide-rich metasiltstone with abundant spessartine garnet and $\mathrm{Mn}$-rich carbonate concretions. Subunit B is similar to subunit A but has less garnet and more metasandstone interbeds. At the base, subunit $C$ consists principally of medium to coarse grained metasandstone with grey metasiltstone interbeds, rare garnet, Mn-rich carbonate concretions which are less abundant than in subunits $\mathrm{A}$ and $\mathrm{B}$, and only minor sulphides.

Sulphur analyses of samples from the Beaverbank unit indicate a potential acid generating hazard, based on Nova Scotia Department of the Environment guidelines which suggest that rocks containing greater than $0.40 \%$ sulphur should be treated as potentially acid generating. Rocks from the Beaverbank unit have sulphur contents as high as $3.4 \%$ and approximately $40 \%$ of the rocks analyzed from this unit exceed $0.40 \% \mathrm{~S}$ limit. Subunits $\mathrm{A}$ and $\mathrm{B}$ have average sulphur contents of $0.70 \%$ and $0.60 \%$ respectively, whereas the sulphur content of subunit $\mathrm{C}$ is only $0.06 \%$.
\end{abstract}

On a eu recours à des analyses lithogéochimiques de l'unité Beaverbank, à North Beaverbank, pour caractériser l'intervalle stratigraphique représentant la gradation du métagrès de la Formation de Goldenville à l'ardoise de la Formation sus-jacente d'Halifax, dans le centre de la partie continentale de la Nouvelle-Écosse (secteur central de Meguma). On peut diviser l'unité en trois sous-unités en fonction de ses caractères lithologiques, chimiques et minéralogiques. La sous-unité supérieure A (horizon de coticule) est principalement constituée de métasiltstone riche en sulfures gris avec concrétions de carbonate riches en Mn et grenats de spessartine abondants. La sousunité $B$ est semblable à la sous-unité A (l'horizon de coticule), mais elle renferme moins de grenats et plus de couches interstratifiées de métagrès. À la base, la sous-unité $C$ est principalement composée de métagrès à grain allant de moyen à grossier avec couches interstratifiées de métasiltstone gris, rares grenats, concrétions de carbonate riches en $\mathrm{Mn}$ moins abondantes que dans les sous-unités $\mathrm{A}$ et $\mathrm{B}$, et seulement quelques sulfures.

Les analyses du soufre des échantillons provenant de l'unité Beaverbank révèlent, d'après les lignes directrices du ministère de l'Environnement de la Nouvelle-Écosse, un risque possible de production d'acides, qui laisse supposer qu'il faudrait traiter les roches renfermant plus de $0,40 \%$ de soufre comme des roches pouvant produire des acides. Les roches de l'unité Beaverbank ont une teneur en soufre pouvant atteindre 3,4\% et environ $40 \%$ des roches de cette unité analysées ont dépassé la limite de $0,40 \%$. Les sous-unités A et $\mathrm{B}$ affichent des teneurs en soufre moyennes de $0,70 \%$ et $0,60 \%$ respectivemnt, tandis que la teneur en soufre de la sous-unité $\mathrm{C}$ n'atteint que $0,06 \%$.

[Traduit par la rédaction]

\section{INTRODUCTION}

Acid rock drainage resulting from ground disturbance of sulphide-bearing slates of the Meguma Group has long been recognized as a major environmental hazard in mainland Nova Scotia. The Cunard Member of the Halifax Formation has received much attention, but the underlying Beaverbank unit is also a potential acid generating unit. Most previous studies of this interval, however, have focused on metallogenetic implications (cf. Graves and Zentilli,
1988). This paper summarizes the on-going research into the lithofacies and geochemistry of the Beaverbank unit in central mainland Nova Scotia.

The Beaverbank unit is approximately correlative statigraphically to the Moshers Island Member in the Mahone Bay area (O'Brien, 1988), and in central mainland Nova Scotia it constitutes the transition from the Goldenville Formation to the Halifax Formation (GHT). The unit is Mnrich and contains numerous coticule (spessartine-rich) horizons. Detailed geochemical studies of coticule-bearing horizons 
have been undertaken elsewhere in the Meguma Group (Graves and Zentilli, 1986, 1988; MacInnis, 1986), in Ireland (Doyle, 1984) and in Belgium (Krosse and Schreyer, 1993). Graves and Zentilli (1988) believed that the Goldenville-Halifax Transition (GHT) has significant metallogenetic potential, and that it is stratigraphically and chemically distinct. The geochemical data presented here characterize the stratigraphic variations in the Beaverbank unit at North Beaverbank, and the sulphur and carbon analyses can be used to assess the acid generation risk that could be created by significant ground disturbance of these rocks.

The Nova Scotia Environment Act (Sulphide-bearing Material Disposal Regulation 57-95) requires that rocks containing $\mathbf{0 . 4 0 \%}$ or more sulphur must be treated as hazardous acid-generating material. Rocks of the Beaverbank unit contain up to $3.4 \%$ sulphur. The content of sulphur and the abundance and mineralogy of the sulphides suggest that this stratigraphic horizon is a potential acid-generating interval and therefore must be approached as an environmental hazard. Leaching tests were not carried out as part of this study but clearly should be undertaken as part of any evaluation of the environmental impact that ground disturbance of this unit may create.

\section{Regional GeOlogy}

The Cambro-Ordovician rocks of the Meguma Group are the dominant bedrock of the Meguma Terrane of southern mainland Nova Scotia (Fig. 1). The Meguma Group consists of two formations: (1) the older Goldenville Formation, which consists of a thick sequence of grey to greenish-grey metasandstones, and (2) the conformably overlying Halifax Formation, which is made up of dark grey to grey-green slate and metasiltstone. The zone of the gradational transition between the two formations has been informally termed the Goldenville-Halifax Transition zone (GHT) (e.g., Graves and Zentilli, 1986, 1988; MacInnis, 1986). The Mn-rich beds of the GHT occur at many localities throughout southern Nova Scotia, and are characterized by the presence of coticule horizons and a thin interbedded sequence of slate, metasiltstone and metasandstone.

Strata of the Meguma Group were paratectonically shortened during the mid-Devonian Acadian Orogeny, at which time the Meguma Terrane accreted to North America. The rocks of the Meguma Group have undergone polyphase deformation to form a series of northeasterly trending, upright, tight to open, locally overturned, blanket folds with anticlinal wavelengths of 2 to $15 \mathrm{~km}$. This multiphase deformation led to several generations of well developed cleavage. The structural fabrics include regional and parasitic folds, axial planar cleavage, crenulation cleavage, regional shear cleavage, kink bands, boudinage structures, and faults. The slates of the Halifax Formation have well developed slaty cleavage and define periclinal folds, whereas the coarser metasandstones of the Goldenville Formation are more gently folded and have poorly developed pressure solution cleavage. Rocks of the Meguma Group were regionally metamorphosed from greenschist to lower amphibolite facies and subjected to contact metamorphism adjacent to voluminous granitoid intrusions.

\section{LOCAL GEOLOGY AND BACKGROUND}

Ryan et al. (1996) suggested a preliminary stratigraphy for the Central Mainland area in Nova Scotia and informally introduced the term Beaverbank unit to describe approximately $400 \mathrm{~m}$ of transitional beds between metasandstones of the Goldenville Formation and dark grey slate of the Cunard Member of the Halifax Formation along the north limb of the Mt. Uniacke Syncline (Figs. 1, 2). The Beaverbank unit is exposed in an almost continuous section along Beaverbank Road at North Beaverbank (Fig. 2). Ryan (1994) published a detailed log of the lithology of the section that included details on the lithologies, grain size, colour, percentage of interbeds, bedforms, sulphide mineralogy and the distribution of diagenetic Mn-rich carbonate concretions. Metrescale thick metasandstone beds occur at the base of the unit with metasiltstone and slate interbeds becoming more abundant upsection until grey slate becomes the dominant lithology. In the uppermost sulphide-rich grey metasiltstone, spessartine garnet-rich rocks (coticules) are abundant and occur as beds 10 to $20 \mathrm{~cm}$ thick. The exact reason for the high manganese content in the coticules is unresolved, but it is generally accepted that the enrichment is a sedimentary or diagenetic process and predates metamorphism (e.g., Clifford, 1960; Schiller and Taylor, 1965; Karamata et al., 1970; Kennan and Kennedy, 1983; Docka, 1985). The Beaverbank unit in Central Mainland Nova Scotia is in the greenschist metamorphic facies.

\section{STRATIGRAPHY AND PETROLOGY OF THE BEAVERBANK UNIT}

The Beaverbank unit has been divided into three subunits on the basis of lithology, chemistry and mineralogy (Fig. 2) (Table 1). The subunits in descending order are: (1) Subunit A, consisting of dark grey metasiltstone and slate, rich in spessartine garnet, and containing a high percentage of sulphide minerals; (2) Subunit B, consisting of slate, metasiltstone, and minor fine grained metasandstone containing significantly less garnet and fewer sulphide minerals; and (3) Subunit C, consisting of medium to coarse grained metasandstone interbedded with metasiltstone, with few sulphide minerals and rare garnet.

\section{Subunit A}

Subunit A forms the uppermost part of the Beaverbank unit (Fig. 2) and consists of finely laminated dark grey sulphiderich slate and metasiltstone with minor metre-scale fine grained metasandstone beds at the base. Tightly buckled bands of $<80 \%$ spessartine garnet occur within the coticule rocks and range from 5 to $50 \mathrm{~mm}$ in thickness. Cleavage is defined in thin section by parallel, elongate muscovite and biotite crystals as well as oriented ilmenite laths in some samples. Polycrystalline pyrrhotite is the main sulphide present, although 

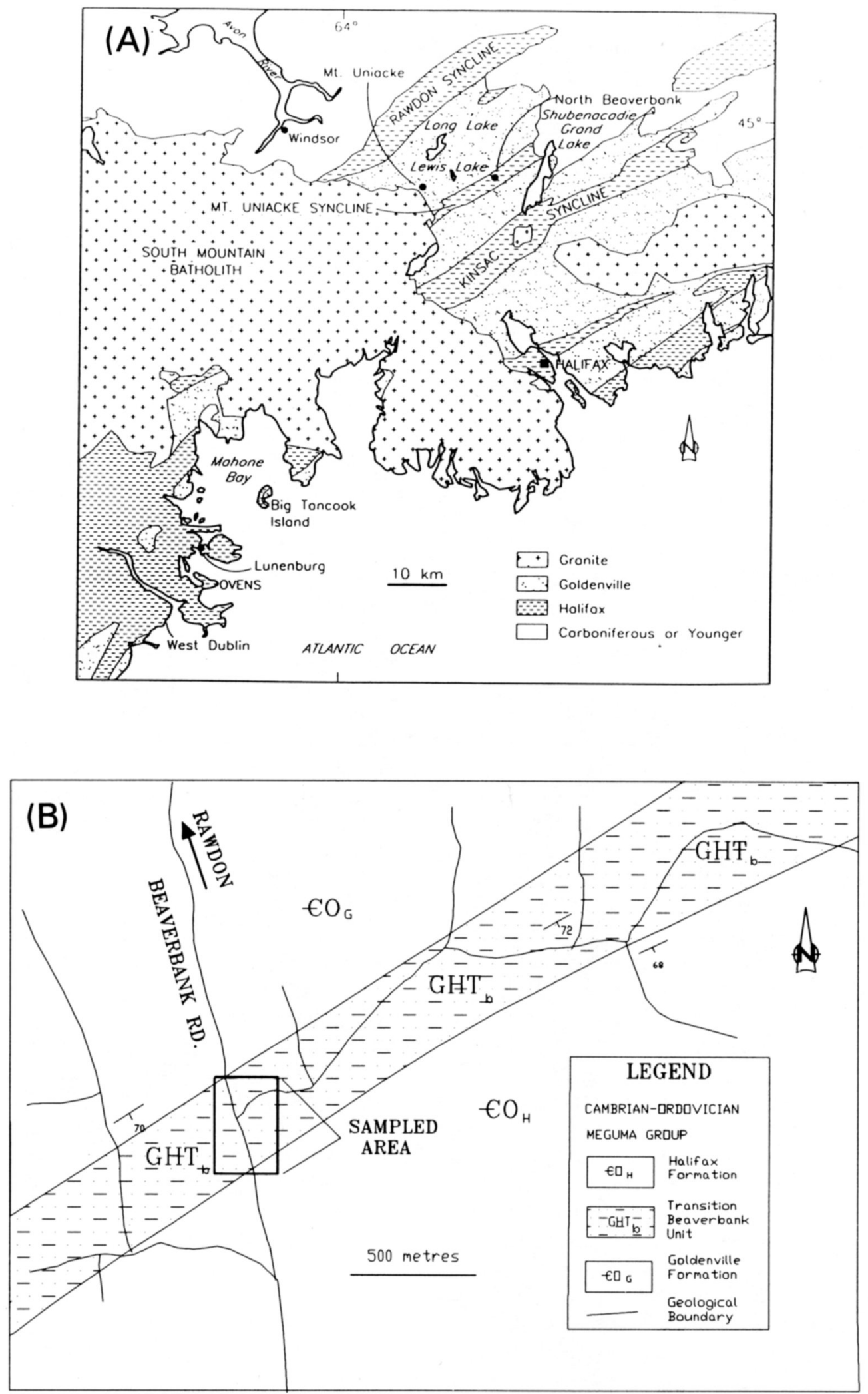

Fig. 1. (A) Generalized geological map of central Nova Scotia showing the location of North Beaverbank; (B) Detailed geological map of the study area, Beaverbank Road section, North Beaverbank.

minor pyrite, chalcopyrite and arsenides are also present and commonly occur as composite grains accounting for up to $6 \%$ by volume of the rock (Table 1 ). Similar observations were made by Haysom et al. (1997) based on other samples from this interval. Other silicate mineral phases in the rocks include quartz, chlorite, muscovite, and minor apatite. The matrix of the rocks is variably calcareous, and elongate $\mathrm{Mn}$ rich carbonate concretions are abundant. 


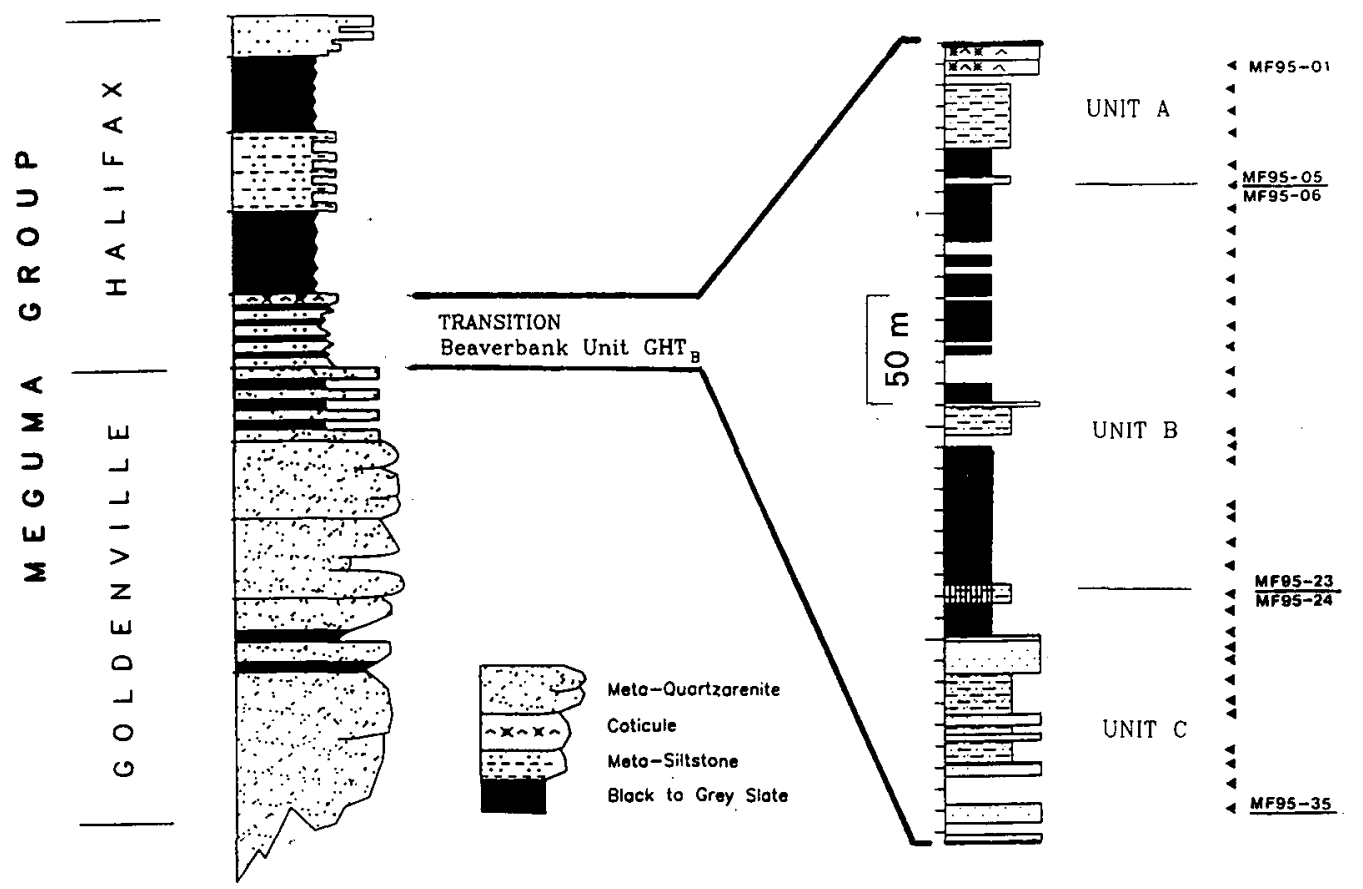

Fig. 2. Generalized stratigraphy of the Meguma Group (after Ryan et al., 1996), and detailed section of the Beaverbank unit showing subunits A, B, and C. Arrows correspond to sample locations (after Feetham, 1996).

\section{Subunit B}

Rocks in the middle subunit $B$ are lithologically similar to those in subunit $\mathrm{A}$, but include more abundant metasiltstone and fine grained metasandstone beds. Light to medium grey slate and metasiltstone beds contain many small $\mathrm{Mn}$-rich carbonate concretions which become less abundant down-section. The lesser amount of garnet in these rocks is the main mineralogical distinction from subunit $A$. The overall percentage of opaque minerals is high for most of the subunit, with ilmenite being the most abundant opaque mineral. Pyrrhotite is the dominant sulphide phase and may form up to $6 \%$ of the rocks (cf. Haysom et al., 1997).

\section{Subunit C}

The lower subunit $\mathbf{C}$ differs from the others mainly in grain size. Medium to coarse grained, light to medium grey metasandstone is the dominant lithology. Many sandstones are crossbedded; thin cross laminated metasiltstones are also interbedded with the metasandstones. Cleavage is less well defined in the metasandstones than in the slates and occurs as widely spaced pressure solution cleavage which can be observed on an outcrop scale. The main silicate mineral phases are anhedral intergrown quartz (up to $87 \%$ by volume), tabular muscovite, chlorite, biotite, and rare garnets. The percentage of total opaque minerals is low. Polished sections were not prepared from subunit $C$ and therefore the specific opaque phases are not known.

\section{Methods}

Thirty-five bulk rock samples were taken at approximately $10 \mathrm{~m}$ intervals over a $320 \mathrm{~m}$ interval of the North Beaverbank section (Fig. 2). These samples are representa- tive of the Beaverbank unit, and reflect the lithological changes within it. Major element analyses were done by X-ray fluorescence at McGill University. Trace element analyses for cobalt, chromium, copper, nickel, and zinc were also determined by X-ray fluorescence whereas gold, silver, barium, lead, rubidium, strontium and zirconium were analyzed by atomic absorbtion at the Technical University of Nova Scotia (TUNS). Total sulphur analysis by wet chemical methods was carried out on all the samples and total carbon, organic carbon and $\mathrm{CO}_{2}$ analyses were determined on every second sample at TUNS. Sulphur determination was carried out using the LECO Induction Furnace and the LECO sulphur titrator; carbon determination was carried out using the LECO Induction Furnace and the LECO carbon determinator. Detection limit for both carbon and sulphur is $0.004 \%$. Polished thin sections were made of samples of MF95-01 to MF95-15 (coticule-rich horizon) and regular thin sections were prepared of the rest of the samples. Electron microprobe analyses were conducted at Dalhousie University for selected silicate and opaque mineral phases (Feetham, 1996). Spearman correlation coefficients for the North Beaverbank samples were calculated for all samples in this study using a 1-tailed significance test (Feetham, 1996).

\section{GeOChemistry}

\section{Subunit A}

Sulphur values in subunit A range from $0.10 \%$ to $1.49 \%$ and have an average value of $0.60 \% \pm 0.26$ (Table 2). The carbon values are also high. The main feature of the subunit is high $\mathrm{MnO}$, up to a maximum of $12 \mathrm{wt} . \%$. The rocks are also enriched in $\mathrm{Co}, \mathrm{Ni}, \mathrm{Fe}$, and to a lesser degree $\mathrm{Cu}$ (Fig. 3). The high concentrations of $\mathrm{MnO}$ in the rocks is contained in the abundant spessartine garnet as well as in 
Table 1. Mineralogy derived from thin sections of the Beaverbank Road section. Sample numbers correspond to the geochemical samples. Percentages are visual estimates only. Samples MF-95-1 to MF-95-15 are polished thin sections, whereas the samples 16 to 35 are unpolished thin sections and therefore only total opaque mineral content was estimated for these samples.

\begin{tabular}{|c|c|c|c|c|c|c|c|c|c|c|c|c|c|c|c|}
\hline $\begin{array}{l}\text { THIN } \\
\text { SECTION }\end{array}$ & QUARTZ & MUSC & GARNET & CHa & BIO & MATRDX & TOURM & SPHENE & CARB & OPAQ & II & PYRR & СНАLCO & PYRTE & OTHER \\
\hline Sub Uate $\mathbf{A}$ & & & & & & & & & & & & & & & . \\
\hline MF95-01 & & & $30 \%$ & $2 \%$ & $2 \%$ & $50 \%$ & & & $1 \%$ & $15 \%$ & $7 \%$ & $6 \%$ & $1 \%$ & $<1 \%$ & arsenide \\
\hline MF95-02 & & & $10 \%$ & & $5 \%$ & $75 \%$ & & & $5 \%$ & $5 \%$ & $3 \%$ & $2 \%$ & $<1 \%$ & & \\
\hline MF95-03 & & & $20 \%$ & & $65 \%$ & $1 \%$ & & & $8 \%$ & $7 \%$ & $4 \%$ & $<1 \%$ & & $<1 \%$ & unknown \\
\hline MF95-04 & & & $15 \%$ & & $43 \%$ & & & & $2 \%$ & $10 \%$ & $9 \%$ & $1 \%$ & & & \\
\hline MF95-05 & & & $20 \%$ & $5 \%$ & $55 \%$ & & & & $10 \%$ & $10 \%$ & $7 \%$ & $1 \%$ & $<1 \%$ & $<1 \%$ & arsenide \\
\hline \multirow{2}{*}{\multicolumn{16}{|c|}{ Sub Unth B }} \\
\hline & & & & & & & & & & & & & & & \\
\hline MF95-06 & & & $10 \%$ & $5 \%$ & $5 \%$ & $63 \%$ & $1 \%$ & & $1 \%$ & $15 \%$ & $15 \%$ & & & & \\
\hline MF95-07 & & & $10 \%$ & $20 \%$ & & $60 \%$ & & & & $10 \%$ & $10 \%$ & & & & \\
\hline MF95-08 & & & $5 \%$ & $10 \%$ & & $64 \%$ & $1 \%$ & & & $20 \%$ & $20 \%$ & & & & \\
\hline MF95-09 & $35 \%$ & $35 \%$ & $5 \%$ & $15 \%$ & & & & $5 \%$ & & $5 \%$ & $4 \%$ & $<1 \%$ & & & \\
\hline MF9s.10 & $30 \%$ & $20 \%$ & $3 \%$ & $5 \%$ & $5 \%$ & & $1 \%$ & & $25 \%$ & $11 \%$ & $4 \%$ & $6 \%$ & $<1 \%$ & & \\
\hline MF95.11 & & $5 \%$ & $1 \%$ & $10 \%$ & $5 \%$ & $62 \%$ & $1 \%$ & $1 \%$ & $5 \%$ & $10 \%$ & $4 \%$ & $6 \%$ & & & \\
\hline MF95-12 & & & & $5 \%$ & $5 \%$ & $78 \%$ & $1 \%$ & $1 \%$ & $5 \%$ & $5 \%$ & $4 \%$ & $1 \%$ & & & \\
\hline MF95-13 & & & & $10 \%$ & $4 \%$ & $70 \%$ & $1 \%$ & & $10 \%$ & $5 \%$ & $3 \%$ & $1 \%$ & $<1 \%$ & & \\
\hline MF95-14 & & & & $10 \%$ & $10 \%$ & $67 \%$ & $1 \%$ & $1 \%$ & $5 \%$ & $6 \%$ & $2 \%$ & $2 \%$ & $<1 \%$ & $<1 \%$ & arsenide \\
\hline MF95.15 & $10 \%$ & & & $5 \%$ & $5 \%$ & $42 \%$ & $1 \%$ & & $30 \%$ & $7 \%$ & $4 \%$ & $<1 \%$ & $<1 \%$ & $<1 \%$ & \\
\hline MF95-16 & $20 \%$ & $10 \%$ & $10 \%$ & $5 \%$ & $5 \%$ & $45 \%$ & & & & $5 \%$ & & & & & \\
\hline MF95.17 & $35 \%$ & $25 \%$ & $10 \%$ & $13 \%$ & & $10 \%$ & & $<1 \%$ & & $6 \%$ & & & & & \\
\hline MF95.18 & $5 \%$ & $7 \%$ & $10 \%$ & $5 \%$ & & $68 \%$ & & & & $5 \%$ & & & & & \\
\hline MF9S-19 & $30 \%$ & & $8 \%$ & $12 \%$ & $1 \%$ & $44 \%$ & & & & $6 \%$ & & & & & \\
\hline MF9S-20 & $15 \%$ & $13 \%$ & $3 \%$ & $13 \%$ & & $47 \%$ & $<1 \%$ & $<1 \%$ & & $7 \%$ & & & & & \\
\hline MF95-21 & $40 \%$ & $10 \%$ & $3 \%$ & $10 \%$ & & $22 \%$ & & & & $15 \%$ & & & & . & \\
\hline MF95-22 & $30 \%$ & $15 \%$ & $5 \%$ & $10 \%$ & & $28 \%$ & $<1 \%$ & & & $11 \%$ & & & & & \\
\hline MF95-23 & $10 \%$ & $5 \%$ & $15 \%$ & $10 \%$ & $2 \%$ & $54 \%$ & $<1 \%$ & $<1 \%$ & & $2 \%$ & & No & POLISHED & SECTIONS & \\
\hline \multirow{2}{*}{\multicolumn{16}{|c|}{ Sub Untt C }} \\
\hline & & & & & & & & & & & & & & & \\
\hline MF95-24 & $80 \%$ & $15 \%$ & $<1 \%$ & $2 \%$ & $1 \%$ & & & $2 \%$ & & $5 \%$ & & & & & \\
\hline MF95.2S & $40 \%$ & $5 \%$ & & $10 \%$ & & $40 \%$ & & $4 \%$ & & $1 \%$ & & & & & \\
\hline MF95-26 & $80 \%$ & $5 \%$ & & $5 \%$ & & $3 \%$ & & $5 \%$ & & $2 \%$ & & & & & \\
\hline MF95-27 & $59 \%$ & $15 \%$ & & $12 \%$ & & $12 \%$ & & $1 \%$ & & $1 \%$ & & & & & \\
\hline MF95-28 & $24 \%$ & $10 \%$ & & $10 \%$ & & $54 \%$ & & $1 \%$ & & $1 \%$ & & & & & \\
\hline MF95-29 & $25 \%$ & $10 \%$ & $8 \%$ & $10 \%$ & & $40 \%$ & & $5 \%$ & . & $2 \%$ & & & & & \\
\hline MF95-30 & $45 \%$ & $10 \%$ & $7 \%$ & $9 \%$ & & $25 \%$ & & $1 \%$ & & $3 \%$ & & & & & \\
\hline MF95.31 & $25 \%$ & $10 \%$ & $1 \%$ & $10 \%$ & & $48 \%$ & & $5 \%$ & & $1 \%$ & & & & & \\
\hline MF95.32 & $81 \%$ & $10 \%$ & & $5 \%$ & & & & $3 \%$ & & $2 \%$ & & & & & \\
\hline MF95-33 & $40 \%$ & $19 \%$ & $<1$ & $10 \%$ & $5 \%$ & $19 \%$ & & $5 \%$ & & $1 \%$ & & & & & \\
\hline MF95-34 & $50 \%$ & $10 \%$ & & $12 \%$ & & $22 \%$ & $1 \%$ & $3 \%$ & & $2 \%$ & & & & & \\
\hline MF95.35 & $88 \%$ & $5 \%$ & & & $1 \%$ & & & $3 \%$ & & $5 \%$ & & & & & \\
\hline
\end{tabular}

abundant Mn-rich ilmenite which contains up to $15.94 \%$ $\mathrm{MnO}$ (Feetham, 1996). Arsenic is also slightly elevated and the rocks contain trace quantities of arsenides (Table 1).

\section{Subunit B}

The sulphur values in subunit $B$ are variable with values from $0.017 \%$ to $3.4 \%$ (Table 2 ). The average sulphur value is $0.70 \% \pm 0.19$, and therefore on average these rocks constitute a potential acid drainage problem. Unlike subunit A, the carbon values for this interval are low, both total carbon and organic carbon. The low carbon values are reflected in the lighter colour of the rocks in this subunit. As might be expected, the silica content of the rocks increases with the increase in grain size of the rocks down-section and sodium and potassium also increase (Fig. 3). The Mn,
$\mathrm{Co}$, and $\mathrm{Ni}$ values are depleted in relation to the overlying beds, reflecting the decrease in abundance of spessartine garnet and associated sulphide phases. Sulphides are present primarily along the cleavage planes in the rocks.

\section{Subunit C}

Sulphur contents in rocks of subunit $\mathrm{C}$ are low, varying from $0.006 \%$ to $0.313 \%$ with an average value of $0.06 \% \pm$ 0.02 (Table 2). This low content may be in part a reflection of the increase in grain size of the interval, although even the metasiltstones in this horizon have lower sulphur values. The Spearman Rank correlation analysis did not indicate that grain size played an important role in the distribution of the sulphur. The carbon content of this interval is also lower than in the rest of the Beaverbank unit (Table 2). 
Table 2. Analyses of Sulphur and Carbon in the North Beaverbank samples. NA = not analyzed.

\begin{tabular}{|c|c|c|c|c|c|}
\hline Sample & Depth & S(Total) & C(Total) & C(Org) & $\mathrm{CO} 2$ \\
\hline Number & Meters & \% & \% & \% & $\mathbf{x}$ \\
\hline & & & & & \\
\hline \multicolumn{6}{|l|}{ Unit A } \\
\hline MF95-01 & 485 & 0.860 & 0.340 & 0.133 & 0.760 \\
\hline MF95-02 & 475 & 0.440 & NA & NA & NA \\
\hline MF95-03 & 465 & 1.490 & 0.427 & 0.300 & 0.466 \\
\hline MF95-04 & 455 & 0.134 & NA & NA & NA \\
\hline MF95-05 & 440 & 0.102 & 0.229 & 0.068 & 0.591 \\
\hline Average S(\%) & & 0.600 & & & \\
\hline & & & & & \\
\hline \multicolumn{6}{|l|}{ Unit B } \\
\hline MF95-06 & 430 & 0.138 & NA & NA & NA \\
\hline MF95-07 & 420 & 0.122 & 0.082 & 0.068 & 0.051 \\
\hline MF95-08 & 410 & 0.069 & NA & NA & NA \\
\hline MF95-09 & 400 & 0.195 & 0.127 & $<0.004$ & 0.470 \\
\hline MF95-10 & 387 & 0.890 & NA & NA & NA \\
\hline MF95-11 & 376 & 1.000 & 0.099 & 0.090 & 0.033 \\
\hline MF95-12 & 365 & 0.980 & NA & NA & NA \\
\hline MF95-13 & 355 & 1.520 & 0.174 & 0.168 & 0.022 \\
\hline MF95-14 & 343 & 0.740 & NA & NA & NA \\
\hline MF95-15 & 333 & 0.550 & 0.165 & 0.131 & 0.125 \\
\hline MF95-16 & 315 & 0.340 & NA & NA & NA \\
\hline MF95-17 & 309 & 0.053 & 0.036 & $<0.004$ & 0.132 \\
\hline MF95-18 & 304 & 0.017 & NA & NA & NA \\
\hline MF95-19 & 281 & 0.480 & 0.065 & 0.045 & 0.073 \\
\hline MF95-20 & 277 & 0.620 & NA & NA & NA \\
\hline MF95-21 & 274 & 3.370 & 0.019 & $<0.004$ & 0.070 \\
\hline MF95-22 & 266 & 0.990 & NA & NA & NA \\
\hline \begin{tabular}{|l|} 
MF95-23 \\
\end{tabular} & 252 & 0.028 & 0.063 & 0.050 & 0.048 \\
\hline Average S (\%) & & $0.70 \%$ & & & \\
\hline \multicolumn{6}{|l|}{ Unit C } \\
\hline MF95-24 & 240 & 0.115 & NA & NA & NA \\
\hline MF95-25 & 232 & 0.009 & 0.055 & 0.040 & 0.055 \\
\hline MF95-26 & 220 & 0.032 & NA & NA & NA \\
\hline MF95-27 & 213 & 0.159 & 0.027 & 0.020 & 0.026 \\
\hline MF95-28 & 210 & 0.011 & NA & NA & NA \\
\hline MF95-29 & 199 & 0.041 & 0.109 & 0.066 & 0.158 \\
\hline MF95-30 & 189 & 0.019 & NA & NA & NA \\
\hline MF95-31 & 183 & 0.006 & 0.028 & 0.021 & 0.026 \\
\hline MF95-32 & 163 & 0.008 & NA & NA & NA \\
\hline MF95-33 & 159 & 0.006 & 0.027 & 0.021 & 0.022 \\
\hline MF95-34 & 149 & 0.006 & NA & NA & NA \\
\hline MF95-35 & 136 & 0.313 & 0.055 & $<0.004$ & 0.202 \\
\hline Average S (\%) & & 0.060 & & & \\
\hline & & & & & \\
\hline
\end{tabular}

Values for sodium and potassium are erratic and seem to be inversely proportional to one other. The $\mathrm{SiO}_{2}$ content of the rocks is as high as $79.9 \%$ and $\mathrm{TiO}_{2}$ is up to $1.1 \mathrm{wt}$ \% (Fig. 3).

\section{Element CORRELATIONS}

Spearman rank correlation coefficients were run for the analyzed elements and also against grain size (Lithology in Table 3). A minor inconsistency exists in the grain size distribution, due to the increased grain size of the coticule horizons which reflects the size of metamorphic garnet rather than the original grain size of the sediments. It is interesting no strong correlations are apparent between grain size and element distribution. The lack of strong correlation between $\mathrm{Fe}$ and $\mathrm{S}$ may be due to the presence of $\mathrm{Fe}$ and $\mathrm{Mn}$ carbonates associated with concretions in the Beaverbank unit. The sulphur shows moderate correlation to $\mathrm{Cu}$. The presence of muscovite, biotite and the presence of feldspar in the matrix of the rocks can explain the strong correlations between $\mathrm{K}_{2} \mathrm{O}$ and $\mathrm{Al}_{2} \mathrm{O}_{3}$, as well as $\mathrm{Rb}$ and $\mathrm{K}_{2} \mathrm{O}$ (Table 3). Nickel and cobalt also show a strong correlation, reflected in the presence of $\mathrm{Co}-\mathrm{Ni}$ arsenide phases and probable association in pyrrhotite. Moderate correlations occur for most of the sulphide-related elements, including $\mathrm{Fe}-\mathrm{Co}$, $\mathrm{Ni}-\mathrm{Fe}$, and $\mathrm{Zn}-\mathrm{Fe}$. Lead and silver also show moderate correlation. Aluminum is moderately correlative with chromium and barium, as are sulphur and carbon. The sulphur-carbon correlation probably reflects the association of sulphides with the Al- and carbon-rich metasiltstone and slate. The correlation of $\mathrm{MnO}$ with $\mathrm{CO}_{2}$ may point to the presence of $\mathrm{Mn}$ rich carbonates which were the probable precursors to $\mathrm{Mn}$ garnets in the coticule horizons. Moderate to weak negative correlations exist for silica against iron, chromium, and aluminium. The dilution of the mafic components by silica in coarser sediments may explain this relationship. 

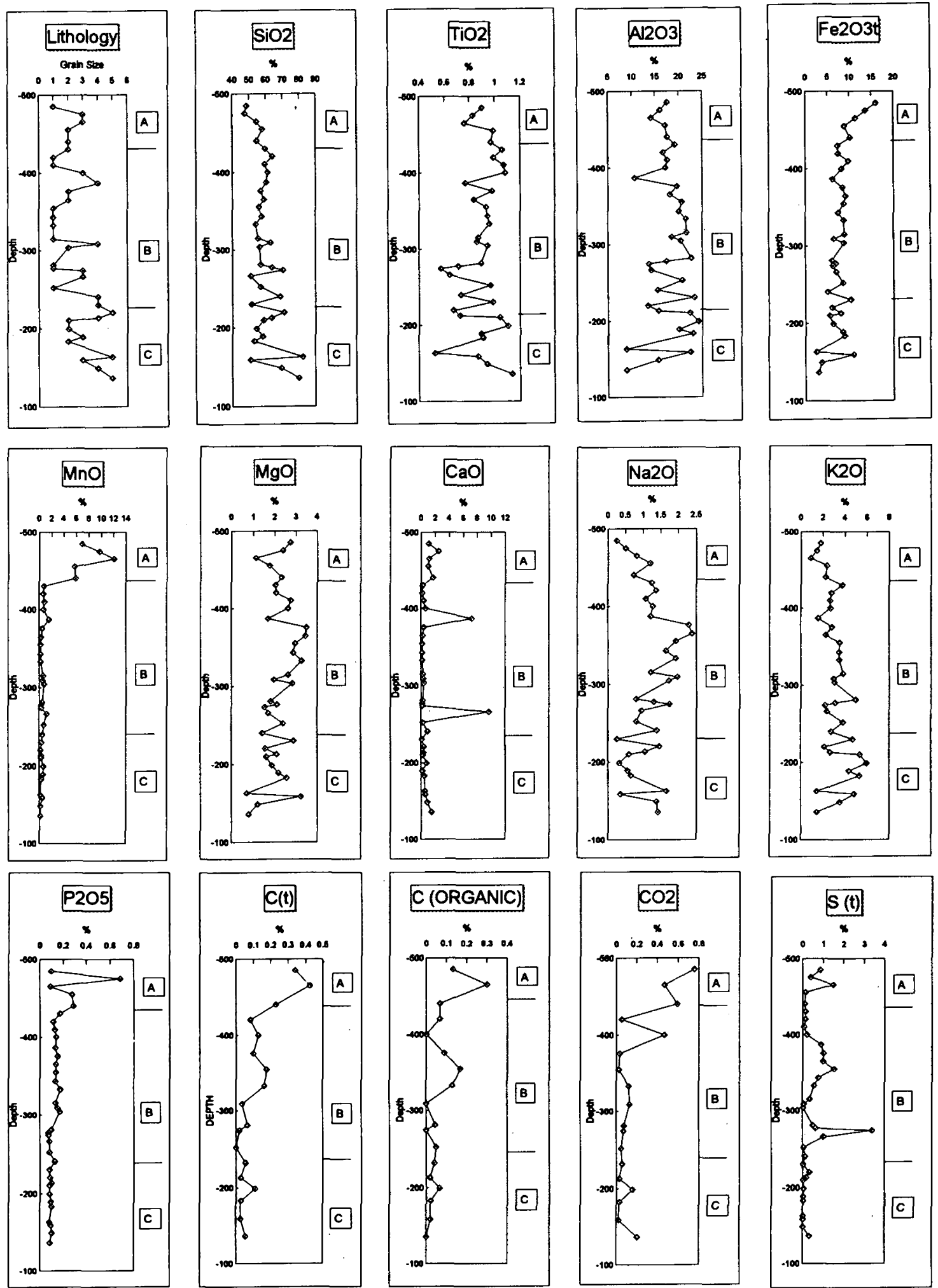

Fig. 3. Plots of geochemical data versus depth (metres of measured section at North Beaverbank; $480 \mathrm{~m}$ is the top of the Beaverbank unit). Lithology $\log$ numbers correspond to grain size: $1=$ slate, 2 = metasiltstone, $3=$ fine grained metasandstone, $4=$ medium grained metasandstone, and $5=$ coarse grained metasandstone.

\section{Discussion}

The distribution of sulphur (Table 2) within the Beaverbank unit indicates that average sulphur contents of both subunit A $(0.6 \% \mathrm{~S})$ and subunit $\mathrm{B}(0.7 \% \mathrm{~S})$ are higher than accept- able limits for sulphur (N.S. Environment Act). In subunit $A$, three of the five analysed samples are above the $0.4 \%$ limit, whereas in subunit $B$, ten of the eighteen samples are above the limit. Subunit $C$ does not appear to represent an environmental problem as no samples have above $0.4 \% \mathrm{~S}$ 

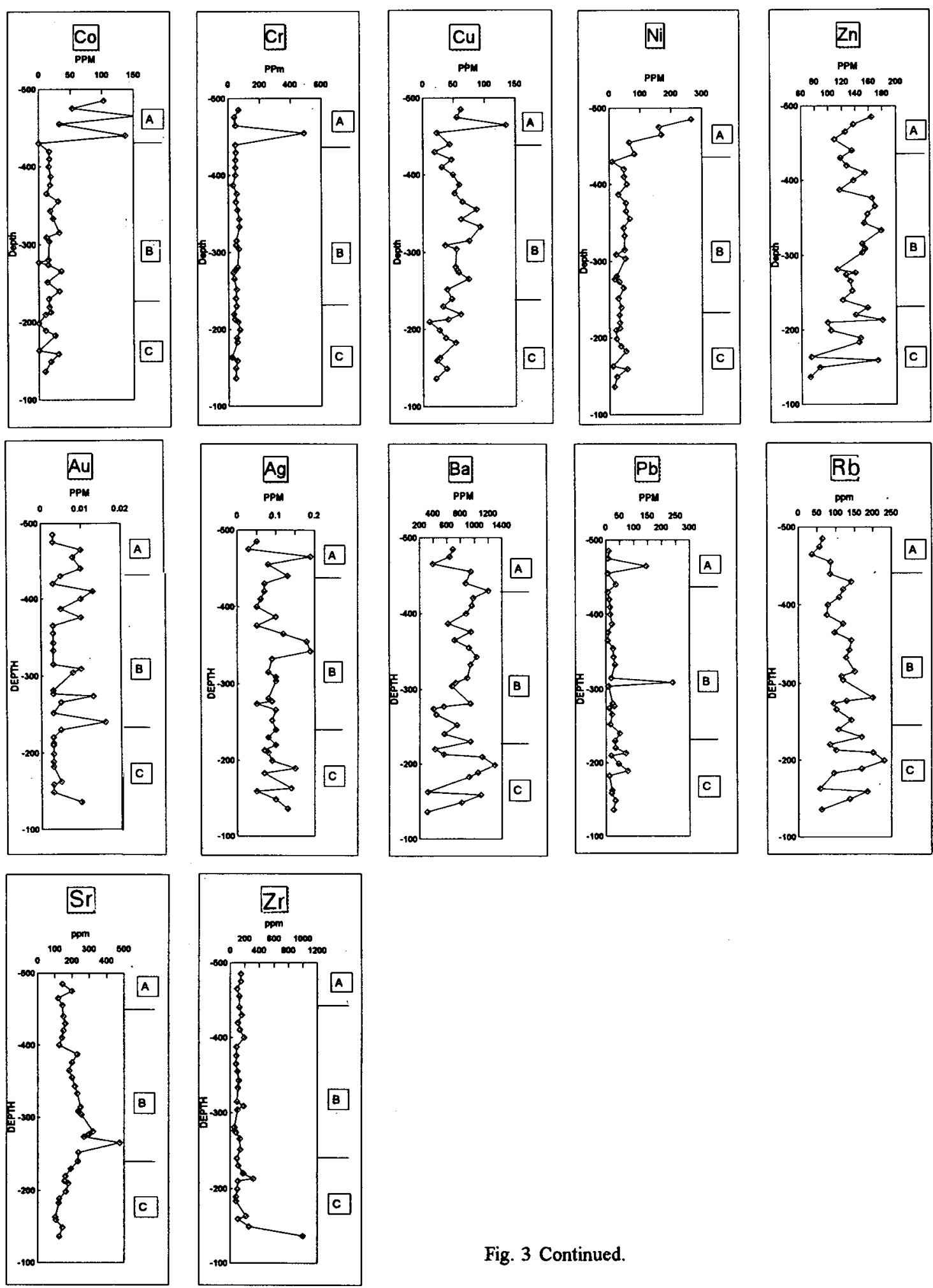

Fig. 3 Continued.

and the average sulphur content is only $0.06 \% \mathrm{~S}$. Graves and Zentilli (1988) analyzed four samples from the correlative Moshers Island Member and the average sulphur content is $0.63 \% \mathrm{~S}$, with two of the four samples exceeding the acceptable limit. The average content from the Moshers Island Member is very similar to the average values from subunits $A$ and $B$ in this study. To further evaluate the potential environmental impact of ground disturbance of this unit leaching

tests are being undertaken at Dalhousie University in cooperation with D. Fox and Marcos Zentilli.

The Beaverbank unit at North Beaverbank represents a distinctive sequence of rocks in the Meguma Group. The mineralogical and textural features are easily recognized in hand specimens, and the geochemistry is distinct. The unit can be mapped throughout the central Meguma terrane and can be correlated stratigraphically with the Moshers Island 
Table 3. Relative Spearman Rank correlations of analyzed elements in samples from North Beaverbank. Strong $= \pm$ 0.84 to 0.99 , Moderate $= \pm 0.67$ to 0.83 and Weak $= \pm 0.50$ to 0.66 .

\begin{tabular}{|c|c|c|c|c|}
\hline POSITVE (+) & & & NEGATIVE (-) & \\
\hline STRONG & MODERATE & WEAK & MODERATE & WEAK \\
\hline & & & & - \\
\hline $\mathrm{K} 2 \mathrm{O}-\mathrm{A} / 2 \mathrm{O}$ & $\mathrm{Fe} \cdot \mathrm{Co}_{0}$ & Lith - Au & $\mathrm{SiO} 2-\mathrm{Al} 2 \mathrm{O} 3$ & $\mathrm{~K} 2 \mathrm{O}-\mathrm{Au}$ \\
\hline $\mathrm{Ni}-\mathrm{Co}$ & $\mathrm{Ba}-\mathrm{K} 2 \mathrm{O}$ & $C(t)-C_{0} 2$ & $\mathrm{Sr}-\mathrm{CaO}$ & $R b-A u$ \\
\hline$R \mathrm{~B}-\mathrm{K} 2 \mathrm{O}$ & $\mathrm{Pb}-\mathrm{Ag}$ & $\mathrm{Cu}-\mathrm{Corg}$ & Lith - Corg & $\mathrm{Rb}-\mathrm{CaO}$ \\
\hline & $\mathrm{Rb}-\mathrm{A} / 2 \mathrm{O} 3$ & $\mathrm{Cu}-\mathrm{C}(\mathrm{t})$ & Lith - Cr & $\mathrm{K} 2 \mathrm{O}-\mathrm{CO} 2$ \\
\hline & $\mathbf{R b}-\mathbf{B a}$ & $\mathrm{Fe}$ - Corg & Lith - Cu & $\mathrm{Rb}-\mathrm{CO} 2$ \\
\hline & $C(t)-$ Corg & $\mathrm{K} 2 \mathrm{O}-\mathrm{Cr}$ & $\mathrm{SiO} 2-\mathrm{Cr}$ & $\mathrm{Au}-\mathrm{A} / 2 \mathrm{O}$ \\
\hline & $\mathrm{s}-\mathrm{Cu}$ & $\mathrm{MnO}-\mathrm{CO} 2$ & $\mathrm{SiO} 2-\mathrm{Fe}$ & $\mathrm{Ba}-\mathrm{Au}$ \\
\hline & $\mathrm{Ba}-\mathrm{A} / 2 \mathrm{O} 3$ & $\mathrm{MnO}-\mathrm{C}(\mathrm{t})$ & & $\mathrm{Cr}-\mathrm{Au}$ \\
\hline & $\mathrm{Cr}-\mathrm{Al} 2 \mathrm{O} 3$ & $\mathrm{Ni}$ - Corg & & $S-K 2 O$ \\
\hline & $\mathrm{Ni}-\mathrm{Fe}$ & $\mathrm{Ni}-\mathrm{C}(\mathrm{t})$ & & $\mathrm{Sr}-\mathrm{Ni}$ \\
\hline & $\mathrm{Zn}-\mathrm{Fe}$ & $\mathrm{Ni}-\mathrm{Cu}$ & & \\
\hline & & $R b-C_{r}$ & & \\
\hline & & $\mathrm{CO} 2-\mathrm{CaO}$ & & \\
\hline & & Corg - Co & & \\
\hline & & $\mathrm{Cr}-\mathrm{Ba}$ & & \\
\hline & & $\mathrm{Cu}-\mathrm{Co}_{0}$ & & \\
\hline & & $\mathrm{Na2O}-\mathrm{MgO}$ & & \\
\hline & & $\mathrm{Pb}-$ Lith & & \\
\hline
\end{tabular}

Member of the Halifax Formation elsewhere in the province. The Beaverbank unit is enriched in $\mathrm{MnO}$ in comparison to average slate and metasandstone and other stratigraphic intervals in the Meguma Group (Graves and Zentilli, 1988; Feetham, 1996).

\section{Acknowledgements}

Funding of this project was provided by the Nova Scotia Department of Natural Resources, Saint Mary's University, and NSERC. Special thanks to Al Sangster and Milton Graves for their reviews and suggestions to improve the manuscript.

Clifford, T.N. 1960. Spessartine and magnesium biotite in coticulebearing rocks from Mile Hollow, Alstea Township, New Hampshire, USA. A contribution to the petrology of metamorphosed manganiferous sediments. N. Jb. Mineral. Abh., 94, pp. 13691400.

DockA, J.A. 1985. Petrology of the origin of Mn-Fe metasediments in New England. Unpublished Ph.D. thesis, Harvard University.

Doyle, E.M. 1984. The coticule rocks of the lower Palaeozoic Maulin Formation in Southeast Ireland. Unpublished Ph.D. thesis, National University of Ireland.
FeEthaM, M. 1996. Lithogeochemistry of the Goldenville-Halifax transition zone (GHT) at North Beaverbank, Nova Scotia. Unpublished B.Sc. thesis, Saint Mary's University, Halifax, Nova Scotia.

Graves, M.C. and Zentilli, M. 1986. Geochemical characterization of the Goldenville-Halifax transition zone of the Meguma Group, Nova Scotia. Geological Survey of Canada, Open File 1829.

---- 1988. The lithochemistry of metal-enriched coticules in the Goldenville-Halifax transition zone of the Meguma Group, Nova Scotia. In Current Research, Part 3, Geological Survey of Canada, Paper 88-1B, pp. 251-261.

Haysom, S.J., Horne, R.J., and Pe-Piper, G. 1997. The opaque mineralogy of metasedimentary rocks of the Meguma Group, Beaverbank-Rawdon area, Nova Scotia. Atlantic Geology, 33, pp. 105-120.

Karamata, S., Kessmann, J., and Okrusch, M. 1970. Ein Paragonitfuhrender granatquartzit im Raum Brezovica, Sudserbien. N. Jb. Mineral. Mh., H. 1, pp. 1-19.

Kennan, P.S. and Kennedy, M.J. 1983. Coticules - a key to correlation along the Appalachian-Caledonian orogeny? In Regional Trends in the Geology of the Appalachian-Caledonian-HercynianMauretanide Orogeny. Reidel Publishing Company, Dordrecht, pp. 355-361.

KROSSE, S. and SCHREYeR, W. 1993. Comparative geochemistry of coticules (spessartine-quartzites) and their redschist country rocks in the Ordovician of the Ardennes Mountains, Belgium. Chemie der Erde, 53, pp. 1-20.

MacInNIs, I.N. 1986. Lithogeochemistry of the Goldenville-Halifax Transition (GHT) of the Meguma Group in the manganiferous zinc-lead deposit at Eastville, Nova Scotia. Unpublished B.Sc. thesis, Dalhousie University, Halifax, Nova Scotia.

O'Brien, B.H. 1988. A study of the Meguma Terrane in Lunenburg County, Nova Scotia. Geological Survey of Canada, Open File 1823.

Ryan, R.J. 1994. Preliminary Investigations of Meguma Group Stratigraphy in the Beaverbank area, Nova Scotia. In Mines and Minerals Branch, Report of Activities 1993. Nova Scotia Department of Natural Resources, Mines and Minerals Branch Report 94-1, pp. 137-140.

Ryan, R.J., Fox, D., Horne, R.J., Corey, M., and Smith, P.K. 1996. Preliminary stratigraphy of the Meguma Group strata in the Central Nova Scotia Region. In Nova Scotia Department of Natural Resources, Mines and Minerals Branch Review of Activities 1995. Edited by D. MacDonald. Nova Scotia Department of Natural Resources Report 46-1, pp. 27-34.

SCHILLER, E.A. and TAYLOR, F.C. 1965. Spessartine-quartz rocks (coticules) from Nova Scotia. American Mineralogist, 50, pp. 1477-1481.

Editorial Responsibility : D. Fox and M. Zentilli 